„Kwartalnik Filmowy” no. 110 (2020)

ISSN: 0452-9502 (Print) ISSN: 2719-2725 (Online)

https://doi.org/10.36744/kf.357

(c) Creative Commons BY-NC-ND 4.0

\title{
Maciej Stasiowski
}

independent researcher

https://orcid.org/0000-0003-3123-6027

\section{No Figures in the Landscape. The Post-Anthropocentric Typologies of Architectural Settings in Science-Fiction Films}

Keywords: architecture;

typology;

film;

science fiction; post-Anthropocene

\begin{abstract}
In the ascending age of automation factories, storage facilities, and server farms, intelligent buildings are becoming less dependent on human maintenance. These new and updated architectural forms do not comply with traditional typologies. From the Vitruvian Man to Modulor, our bodies were the measure of most constructions. Yet automation renders new constructions incompatible with patterns of human habitation. This article focuses on the iconography of buildings designed to operate with little to none human interaction, providing an insight into how such settings influenced recent (last decade) science-fiction films like Blade Runner 2049 (dir. Denis Villeneuve, 2017), Captive State (dir. Rupert Wyatt, 2019), I Am Mother (dir. Grant Sputore, 2019), or Transcendence (dir. Wally Pfister, 2014). In each of them, artificial intelligence is an intrinsic composite of the environment, terraforming a post-anthropocentric reality of data centres, automated warehouses and drosscapes.
\end{abstract}


We are living in the age of storage, and there seems to be no way out of this warehouse. Volumes are vast, boxes black, but the exact input/output remains unknown. Designed with security in mind, ideal buildings offer no orifices to glimpse through, no access. They are impenetrable, although their contents are already available on-line. Nevertheless, without gluttonous energy consumption, such digital transparency would not be assured.

Data centres sprout all around the globe and we are hardly ever given opportunity to see what this increasingly popular type of architecture actually contains. Moreover, these user-proof structures are an example of a proliferating architectural typology that does well (or even better) without constant human overseers. Increasingly, the maintenance of automated warehouses, server farms, and loading halls is down to "post-anthropocentric" algorithms. Spaces safe enough for keeping data do not necessarily have to be comfortable for their supervisors, which becomes a crucial parameter in emergent prospects for architecture designed with no bodies in mind.

Artificial environments are radically transforming the look of our urbanized planet, and as new kinds of spaces necessitate viable designs, human future might not simply be only about limiting our harmful impact on the ecosystem, but it might also involve coming to terms with a mechanistic architecture that we are already building. Contemporary automation now takes the form of the vast agricultural fields, endless factory floors and blank data complexes that characterise the conditions of machine landscapes. ... Just like today, the real robots of our cities of technology are ourselves, mere components in a planetary-scaled robot, tending to the solar mirrors, harvesting the protein worms and mining our e-waste for rare earth. ${ }^{1}$ Cinema has been treating us with graphic imaginaries of such speculations at least for a decade.

\section{Introduction}

What does it mean to design architecture in the post-anthropocentric age? Definitely not only resourcefulness and futureproofing the built habitats we have created. Such paradigm must also include coming to terms with our own deterritorialization. Buildings ought to be sustainable, drawn and/or modelled with cohabitants in mind, either animal or plant-based. If the Anthropocene is likely to encourage a thorough reconsideration of our habitual practices, then buildings should steer away from being seen as human interaction labs, literally becoming evolving environments.

This is the opposite of autofacs, as put forward by Philip K. Dick's short story. Autofac ${ }^{2}$, written in 1958, tells about a fail-safe scenario for the country's economy after a man-made apocalypse. In the aftermath of a nuclear war, mankind is pushed back to cave dwellings. Defenceless, exhausted, yet far from clueless, the survivors have come to depend on their ancestors' wisdom, by which all industries had been prepared for a doomsday scenario. Fully automated production lines were created, and a self-sustaining distribution system inaugurated, in order to propel capitalism independently of market economy. After the dust has settled (though radiation might still be up in the air), the remnants of humanity decide to take back control. In doing so, they hack the system, bypass the source code and log into user's interface, as every operating system must have one. Autofacs never 
halted their production-distribution pipeline, defending their premises from friendly trespassers, just as they would from imposters. Dick's farcical solution, mocking cold war's MAD think tanks, turns out to be possible solely by means of programming, namely by inputting a logical error in the factory's command loop. If relinquishing control can be done only through a consumer complaint, then the nature of the complaint needs to be nonsensical enough for the machine to go haywire. Therefore, the characters ignore preconceived answers on a feedback sheet concerning unsatisfactory quality of milk, typing in that "the product is thoroughly pizzled". Back in the day, the machine was stopped, but before expiring it had managed to send out its seeds to other planets.

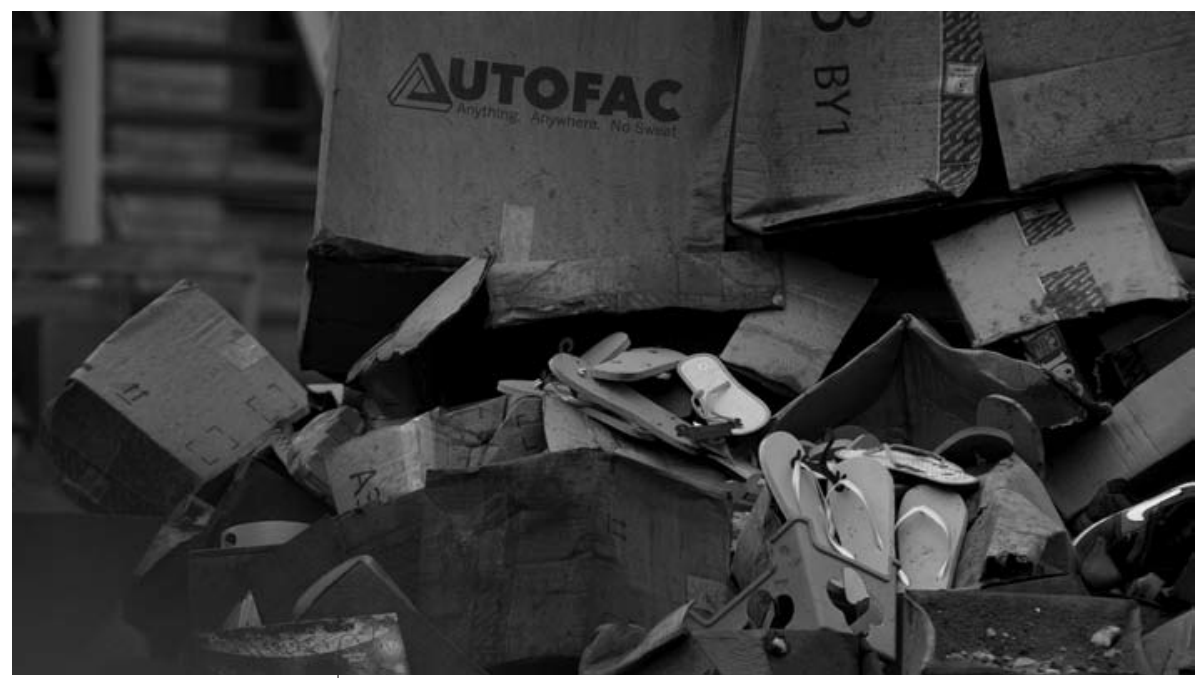

Anything. Anywhere. No Sweat from Philip K. Dick's Electric Dreams: Autofac (dir. Peter Horton, 2018)

Jumping sixty years ahead, we land in a non-speculative future that supports its customers with recursive loops of contemporary autofac procedures. In a film adaptation of this tale, an episode of Philip K. Dick's Electric Dreams (2018), the director Peter Horton visualizes the automated factory as a behemoth Amazon Warehouse, with carrier drones infesting its airspace, making fulfilment centre's interiors even more crowded than on a busy day on Earth. No human activity detected with infrared sensors. But in Travis Beacham's script implementing vulgar vocabulary turns out to be only the initial step of a planned interception, not to mention that expressions such as "pizzled" are less inappropriate than simply dated.

In a global trend to embed intelligence in designs, networking their various components and infrastructure, we could ask: what lies beyond the smart city? A thing or two could be spied through Jenny Odell's altered Satellite Landscapes, especially her Waste Landscape and Manufacturing Landscape series. Here sprawling industrial structures are cut out from the terrain they delve into, presenting the viewer with abstract, constructivist shapes that are as vital to our normal functioning as they are skimmable. Concealed, as Odell described her works. Much of the strangest architecture associated with humanity is infrastructural. We have vast arrays of 
rusting cylinders, oil rigs dotting wastelands like lonely insects, and jewel-toned, rhomboid ponds of chemical waste. ... These mammoth devices unblinkingly process our waste, accept our trash, distribute our electricity. They are our prostheses. They keep us alive and able, for a minute, to forget the precariousness of our existence here and of our total biological dependence on a series of machines, wires, and tubes, humming loudly in some far off place. ${ }^{3}$ Industrial non-sites, warehouses, and "drosscapes" 4 that lie outside the city's perimeter, depicted in a Hopperian fashion on the canvasses of Jeffrey Smart's, an Australian painter. The same sites constitute an expanding array of settings in contemporary science fiction films. Backdrops and sets for its future nostalgias shifted in the last few decades from hi-tech space stations to manufactured wastelands, where strata of failed human endeavours - rusting factories, garbage heaps, and other wastelands - amass, weathered, perforated and corroded. Land art has always been about humans intervening into Nature. Now, without the capital ' $\mathrm{N}$ ', artists like Edward Burtynsky testify with their projects that art has already seeped through cracks in the land, clearing the stage for commercial waste. The new environment is a by-product of progress, and as such it arises as the ultimate scenery for speculative fictions - earthbound not by choice, but necessity.

Architecture of the new millennium swapped skyscrapers for landslides, solitary objects for complexes; in each case, Rem Koolhaas's notion of "bigness" abounds ${ }^{5}$. XL became as much a design paradigm as its own typology, allowing buildings to grow beyond scale, urban 'islands' to nurture their own microclimates and infrastructures to sprawl out horizontally. Envisaged as logistic centres, these distributed units operate under one algorithm. Among the feature films made in the last decade, of interest here are those in which the stage has been set for ascending typologies of the data centre, the automated warehouse, and the "drosscape", intended as developing countries' alternative to the congested cityscapes of Blade Runner lookalikes. Even in that film's long-awaited sequel, we see them intertwined with rarefied fields of scrap metal, as we would in the tar-black shoe boxes $^{6}$ of a data centre in the latest instalment of the Terminator franchise - they are like volumes (masses) to the negative forms of Michael Heizer's North, East, South, West (1967).

\section{Typologies and prototypes}

What follows is a 'historical' typology, because contemporary building types rely on models forged during the First Industrial Revolution, and evolving into the prefabricate concept during the heyday of the International Style. This typology forced its way through to a post-industrial re-programming of abandoned loft and factory spaces, let alone private re-adaptations of warehouses. New purposes for long defunct building types were found in the process, while some of them displayed a strong military provenance, like post-war bunkers and silos repurposed for data storage. The origins of typological classification can be traced back to the $18^{\text {th }}$ century, when it was devised as a form of taxonomizing historical architectural forms. The ascending popularity of evolutionary theories had an impact on realms outside of natural sciences, while fields like urban planning intended to reinforce its rationale with a diachronic methodology. In the $19^{\text {th }}$ century, architects wanted to turn their discipline into science, emphasizing its heritage, whose nobility 
stemmed from a creative reuse of ancient Classicism. Unsurprisingly, the conception of having left 'type' rests in both cases on particular understandings thereof. The first stems largely from the Beaux-arts and Antoine-Chrysostome Quatremere de Quincy's ... work, and the second from the perceived failure of the reclaiming of type in early postmodernism to revive 'meaning' in architecture through typologies of the past... 'While Quatremere de Quincy was connecting past, nature and form on the basis of type, Jean-Nicolas-Louis Durand put emphasis on genre (or category), dismantling buildings on paper by means of grids and axes, and classifying them by programmes of activities hosted within. The same approach would prove futile in the $20^{\text {th }}$ century, because scientific purity ignored context, expecting typologies to exist in a formal void. Forty years ago, Aldo Rossi remarked on the fluid character of architectural forms. The type developed according to both needs and aspirations to beauty; a particular type was associated with a form and a way of life, although its specific shape varied widely from society to society. ${ }^{8}$ Nevertheless, not only in his view the typological project failed in postmodernity. The decades following the Second World War began to witness mass dereliction or utter transformation of early Modernist spaces. The purpose of a building would often clash with new programmes, themselves changing over the course of months, not even years. Postmodernism failed in its most clearly articulated goal - the relation to history - precisely because it sought a fixed typology of buildings and imagined that each historically derived type could invoke the institutions and subjectivities in which it had been originally formed. ${ }^{9}$ After Durand and Modernist functionalism, it was safest to define type as a frame within which change operates ${ }^{10}$. For example, writing on Ludwig Mies van der Rohe, Ralph Moneo noticed that in constructing his building, [Mies] seizes this space and in doing so he constructs a building characterized not by its use - as a school, hospital, church, etc. in the manner of the nineteenth century - but a "space" in which an activity is produced only later. ${ }^{11}$ Architectural typology is therefore seen as a programmatic container, although activities intended for it should not be permanent inscriptions but stay prone to rewrites.

If we are to look at the tradition of formal types through their relation to urban infrastructure and history, engaging with the 'body organs' metaphor, we might ask about vitality of functions carried out by specific typologies of data bunkers and automated storages/warehouses - both adapting to derelict industrial (or even military) structures. They depend in an ambiguous way, yet to a great extent, on context (as nodes in a network, although located on urban peripheries), due to which the smart city enterprise remains fully operational. Are they like the circulatory system and hippocampus? Quite paradoxical is the fact that such (infra)structures are perceived by society as 'invisible', deluded by the pervasiveness of ubiquitous computing - addressed, in turn, by a range of projects that focus on visualizing the Internet's material infrastructures, like Internet exchange points or fibre optic submarine cables.

Re-adaptability is exactly among the boiling points at which typological concerns become irrelevant. Many data centres are far from ideal facilities built specifically for this purpose. Instead, cold war era bunkers, empty warehouses or various industrial type enclosures are retrofitted to contain server stacks. Then there are new projects, like Snøhetta's The Spark (2018-), conceived as multi-purpose activity centres hosting 'clouds' as their pivot - from them come massive 
amounts of heat to power facilities for the gyms, swimming pools, libraries and cinemas located inside the complex. Still, such blueprints are more often 'forecasted' than actually implemented, as in the case of Klaus Schwab's fourth industrial revolution (in architecture) that could fully take hold by means of a digitally reprogrammable space [thanks to which] buildings will be able to instantly shift purpose to serve as a theatre, gymnasium, social centre, nightclub or whatever, thus minimizing the overall urban footprint. This would allow cities to get more from less ${ }^{12}-$ remember that a data centre is neither a clear-cut typological category, nor is it exactly a predetermined form ${ }^{13}$. Either a box, bunker, or a warehouse - its contents are as good as malleable and can be recomposed in the enclosure for best (cooling) efficiency. This way new typologies are growing into historical ones, as in the case of Amazon's fulfilment centres combining those of a storage and a loading hall - a proto-industrial form as basic as the proverbial primitive hut.

A dispersed understating of new types, always in relation to networked urban infrastructures, repositions them - as Rossi wanted - in relation to the megacity and its boundary. What matters is their programmatic (re)encryption and adaptability. The machine landscapes depicted in Blade Runner 2049, i.e. agglomerations where urban sprawl is not seen as aberration but the zeroth degree of panurbanity, place the architectural types discussed as cells in an ever-growing body of the new city. It's a city that doesn't exist on a singular point on a map anymore, it's a city that is now distributed across the entirety of the planet. Architecture once existed in singular sites and that's the way we used to conceive of it, but now in a networked world the city is this planetary-scaled construction. ${ }^{14}$

In this sense, it is a locus without a genius, a post-anthropocentric landscape animated by ubiquitous intelligence, containing atrophying shanty towns and a hypertrophy of congested downtowns. Containing exclusion zones of 'autofac' areas - places where the system lags. Traditionally, human figure was conceived as the basis for architectural measurements, but these new typologies have no need for preserving an anthropocentric image at their foundation(s). For the Vitruvian Man, this is a no-go zone.

\section{Body-building}

Simon Stålenhag's Tales from the Loop (2014) book, recently adapted into an Amazon Prime Video series from his paintings and short stories, lures the viewer with an unusual clash of Arcadian sceneries and sparse figures, like specks of dust in a field. It is a man-made environment, in which wheat fields surround a meteorite space station, and riverbeds flow over iron giants, seemingly out of order, but most probably in sleep mode, saving batteries. What draws the viewer into this world is not even the displacement - hi-tech detritus alongside post-industrial regionalism. Rather, it is the sudden realization that humans were never a compatible match to lakes, forests, and mountains in terms of scale. Unlike giant mechs and robotic beetles which seem like Earth's proper inheritors.

In the 'post-Anthropocene' issue of Architectural Design, guest-edited by Liam Young, the focus lies mainly on windowless buildings, industrial complexes, and automated ports that are scaleless by design. We may feel unwanted in machine-run warehouses, which engineered solutions only confirm. At the scale of these 
infrastructures we do not register; we are just a discoloration, a dead pixel thoroughly embedded in the grain of technology and indistinguishable from the systems that surround us. ... The uncomfortable reality for a culture that does its best to ignore them is that they are central to the production of our urban environment..$^{15}$ How to wrap our (still utterly anthropocentrically-wired) minds around architectures that do not reflect our proportions in any of their details, maybe aside from control interfaces? Our thinking is irrevocably informed by translating the divine image through the image of man, and echoing it in the dimensions of Roman temples, caryatids and atlases standing on plinths, let alone corridors intended to be traversable on foot, or the enfilades reinforcing an optical illusion created from our vantage point. Human corporeality was invisibly inscribed in stone, to make sacral spaces magnificent and intimidating. Ancient craftsmen once measured using parts of the human body: the cubit is based on the length of a forearm; the inch, the length of a thumb. Le Corbusier designed his buildings based around the Modulor... In the age of the network, however, the body is no longer the dominant measure of space; instead it is the machines that occupy the spaces that now define the parameters of the architecture that contains them ... [,] whose form and materiality is configured to anticipate the logics of machine perception and comfort rather than our own. ${ }^{16}$

Returning to speculative fictions on screen, like the 2018 rendition of Dick's Autofac, we notice how impermeable the new machine world order is. The Amazonesque warehouse of its nuclear year zero is a fortress. Carrier drones raid the airspace and are hunted down by post-consumers living on the edge. When a small group of survivors led by Zabriskie (Juno Temple) manages to get past the fortifications, the protagonists can finally grasp the shape of autofac's HQ. Massive as a rock formation, the AI refuses access to its stories below ground, each of which is busy with swarms of drones hovering over the 'factory floor'. In terms of efficiency, this is an ideal dispatch zone many companies strive for, precisely because it is independent from anthropogenic errors and interferences with human assets. Systems seem to operate here at top speed, and as far as humans are provided (by force) with consumer products, while being kept away from the control room, everything works well. Unfortunately, a hero is required to kill his dragon.

Vitruvius wrote about the dimensions of a Doric column as derived from measurements of the human foot. Whose cyber-foot should be taken as the base for future measuring units? Such questions must have already been taking shape when the first auto-reconfigurable architectural constructs were programmed in the 1960s. John Frazer's experiments with self-generating architecture were based on repeatability of simple structural units, as in his Reptile (from rep[eatable] tile[s]) system, commenced in 1966. Constructions would arise from iterations of this standardized unit. The Vitruvian Man's legibility was contested already in the $17^{\text {th }}$ century by Claude Perrault, supplanted by descriptive geometry, and subsequently redefined by Le Corbusier's Modulor - making tall policemen from crime novels, as the architect once remarked, ideal inhabitants of his prefabricated blocks. The $21^{\text {st }}$ century promises a return to an abstract system of sizeable ratios (SI). Film texts were eager to associate them with the area most obsolete for this debate - the Vitruvian scope of associations with universal (and thus divine) proportions. Challenge the human body, HAL, and you challenge God! 


\section{Cinematic landscapes: case studies}

In Manufactured Landscapes (Jennifer Baichwal, 2006) Edward Burtynsky's photographs gain the fourth dimension. We are allowed much more than just a glimpse behind the scenes. The artificial landscape and its 'plastic' picturesqueness, before it coalesces into a perfect photo shot, simply rolls before our eyes, although Burtynsky would rather it remained still. In Baichwal's film we watch scrap metal collectors cut the carcass of a cargo ship into pieces. We behold uniformly dressed assembly line workers gather during a cigarette break. His camera's lens is directed at a kind of land art, although instead of an artist's grand gestures of making incisions into the earth, his protagonists are industries producing waste at a much greater scale. They are changing the environment long-term, while transforming landscapes in an instant. The beauty he captures might not be classical, and it doesn't please the viewer with a harmony of golden sections, but it breeds nostalgia for an unprocessed world, removed to a fairy-tale past, from before the Industrial Revolution.

\section{a) Are drosscapes a typology?}

Burtynsky's shutter provides another way of looking at the Anthropocene and its 'thereafter', which involves not primarily irreversible pollution with carbon dioxide, greenhouse gases and unmanageable waste production, but literal terraforming. Alan Berger referred to the industrial earthworks using the term drosscapes when Burtynsky's project was already underway, although the latter did not engage with this theoretical stance in his publications or TED talks. According to Berger, a drosscape: introduces and explains the ways in which contemporary modes of industrial production, driven by economical and consumerist influences, contribute to urbanization and the formation of waste landscapes - meaning actual waste (such as municipal solid waste, sewage, scrap metal, etc.), wasted places (such as abandoned or contaminated sites), or wasteful places (such as huge parking lots or retail malls). ${ }^{17} \mathrm{He}$ characterizes dross as emerging from two processes - horizontal urbanization (sprawl) and amassed leftovers from production. Actually, he opts for quite the opposite; he cites Manuel de Solà-Morales, who argues that architects should let such sites be, rather than regulating them through design, disputing that they should let them be. Instead, planners treat them like disaster sites and fight to keep their differences and design to resist planned continuity, using the differences of terrain vague [compared to the exaptation process in evolutionary biology - M. S.] as motivation for the architectural project. ${ }^{18}$

In Berger's classification, dross is the landscape of leftovers, a space that lies in between the stim (short for stimulus, although Lerup also collates the term with stimmung or ambiance of technologically-accentuated city attractions ${ }^{19}$ ), which, in turn, includes (infra)structures built and developed for human use. While these two main 'typologies' not necessarily shy away from megalomania, when it comes to scale, "drosscape" is explicitly recognized as a sprawling disarray - the result of a man-produced site. It would be difficult to treat it as symptomatic of proper architecture. This example serves then as an introduction to spatial concerns in 


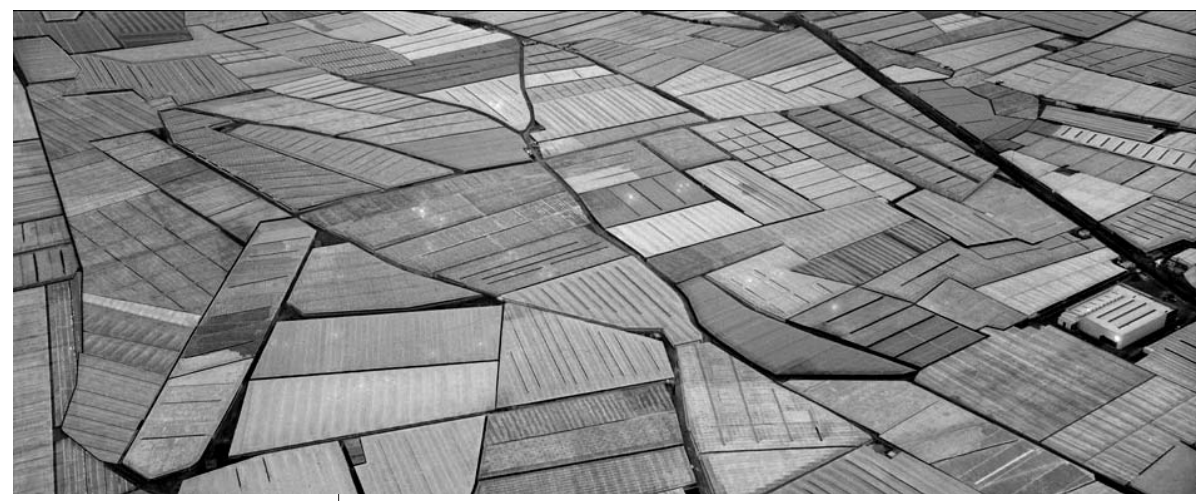

Processed landscape from Blade Runner 2049 (dir. Denis Villeneuve, 2017)

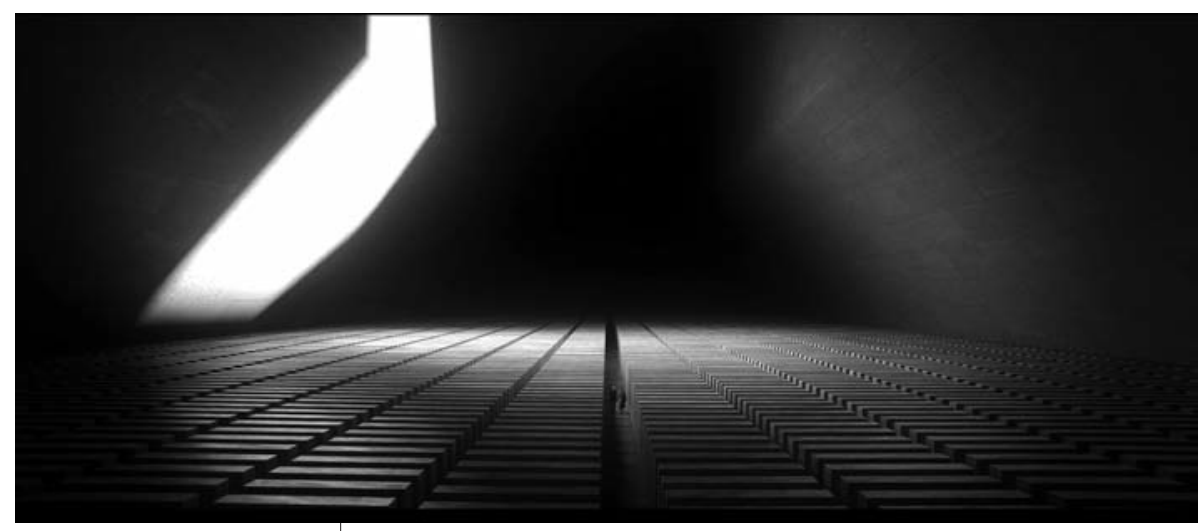

Library of pre-Black Out analog data from Blade Runner 2049 (dir. Denis Villeneuve, 2017)

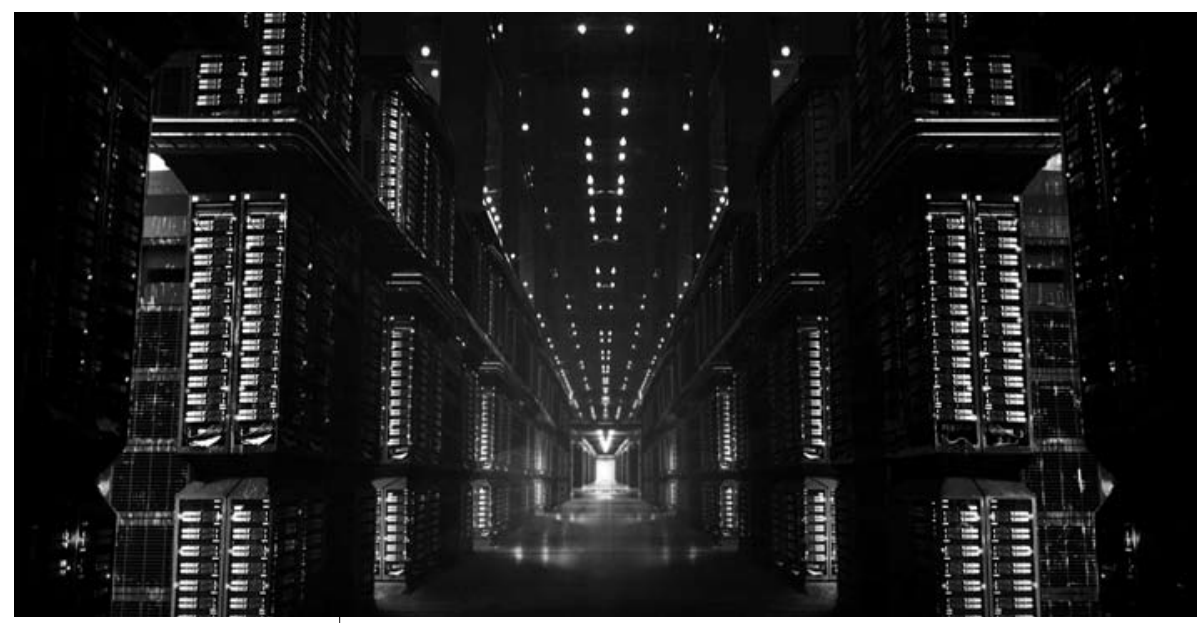

Data centre looking like a city at night from Blade Runner Black Out 2022 (dir. Shinichirō Watanabe, 2017) 
speculative fictions, rather than a full-fledged discussion of a post-industrial form at its terminus. However, it does point to two traits pivotal for subsequent case studies - a displacement of human corporeality, and a post-human recycling of modernist concepts. Additionally, the treatment of "drosscapes" in hard-boiled science fiction reminds us to look for jet lags to futuristic visions not in congested urban centres of cutting-edge smart cities, but on their peripheries. While it definitely looms as an epitaph for the industrial age, it is turned into a menacing backdrop in fiction; one that grounds all stargazing ventures.

An ecological cyberpunk plot is just around the corner. It would not be a turbulent (camera) pan if we proceeded from Burtynsky's images of Californian oil fields, hills formed from millions of tires, and oil tanker cemeteries in the midst of their deconstruction in a third world country, directly into Denis Villeneuve's Blade Runner 2049 (2017). Its opening scenes or the scrapheap exploration episode half-way through the film are a reflection of Burtynsky's photographic essays. The architect Liam Young comments: Today the front line of robotics and automation is found on the periphery. Large-scale shipping ports, massive factories, unmanned energy and agricultural fields, industrial data centres and so on constitute the bleeding edge of applied autonomous technologies.... All of the spaces in the film that we actually find humans in are ruins of these automated technologies. We see the orphans gathered together in the rusting hulls of computer-controlled container ships, scavengers live among the trash dropped by carrier drones, ${ }^{20}$ and instead of space station hi-tech, we contemplate a future where minimizing our footprints means leaving boot marks on distant soil; only in Villeneuve's 2049, the planet that has been turned into one vast humanprocessed territory deals in stim and dross in sharply unequal proportions.

Among the featurettes accompanying the film, there is a 15-minute animation Blade Runner Black Out 2022 (2017) by Shinichirō Watanabe - a prequel to events depicted in the film, which explains one of the threads crucial to the plot. It links directly to a sequence in Blade Runner 2049, set in Wallace Corporation's building. In Watanabe's short two replicants embark on a mission to destroy all magnetic backups in the archives. Other cells will start the 'fireworks' at the remaining data centers. All records on the ground will be erased, ${ }^{21}$ as Iggy Cygnus tells Tixie on their drive to one of such outposts. When K (Ryan Gosling's character) visits the archives of the Wallace Corporation in Villeneuve's film, the Black Out is a memory, yet as vivid as John. F. Kennedy's assassination. Where were You at the time $?^{22}$ - asks the clerk, while leading K to a spacious hall. Not really a data centre - it resembles a museum for EMP-damaged media. Calling the interior minimalist doesn't fully convey its austerity, which is primal and monumental at the same time. Rows we see are library shelves, hidden under elegant wood casings. Inside them bits and pieces of analogue data are stored. The world of Blade Runner 2049 witnesses the failure of networked systems and loss of faith in digitized storage. It recuperates, however, along with Niander Wallace's production of a new breed of replicants.

\section{b) Automated warehouse}

Rob Hart's novel The Warehouse (2019) is set a few years into the future with warehouses the size of small towns. Human workers are already managed like drones, allowing the reader a look at an AS/RS (automated storage and retrieval 
system) through the eyes of novice employees. Nevertheless, an automated approach is evident, making it all the less humane, sustaining the spark for this present-day reimagining of Upton Sinclair's Jungle (1906). This place was designed to take away choice. It was designed to beat you into submission. ${ }^{23}$ We enter the dark side of online shopping, becoming acquainted with a technology that is already much closer than the proverbial horizon. A picturesque soullessness reminiscent of Burtynsky's photographs hasn't changed much since the heyday of the First Industrial Revolution, although now its alleys are designed wide, not to accommodate crowds of workers, but for machines to freely operate. Ben Roberts is a fellow documenter, though with a more upfront social agenda. His Amazon Unpacked (2013) takes focus on the working conditions in a warehouse, and its impact on a former coal-mining town (Rugeley). Contemplative, Rodin-like figures are seated in front of computer screens, reclining in chairs during coffee breaks, or posing in front of infinite perspectives of rows of shelves, dressed in the unskimmable bright orange. Other photographs show empty interiors, gaping, devoid of any human presence. No trace left on slippery clean floors, no shadows cast on side walls. The warehouse captured in Roberts's photography is a library for machines. ...This is a space organised by efficiency algorithms and inhabited by the human components of Amazon's global logistics robot. ${ }^{24}$

But the self-operating warehouse is as much a storage as it is a loading bay, and strictly defined sequences of loading and unloading operations were written into its use. Only now, instead of railways and ramps located near them, 'robotic arms' are being designed to handle and bridge this distance. Configurations would repeat, geometries would be copied throughout centuries. Since its origins in Manchester's cotton mill industry, the main function of the warehouse necessitated increasing its capacity. It was inevitable to pursue engineering solutions that would make them true 'churches of modernity'. The size of these buildings was matched by a sophistication in planning that helped to facilitate the movement of large volumes of goods into, through and out of the warehouses. ${ }^{25}$ Despite $20^{\text {th }}$-century 'reprogramming' of warehouse interiors into private, studio, and at times domestic spaces, human scale was of scarce importance. Automation is thus nothing but the next stage in this typology's transformations towards maximal productiveness.

Automated solutions aren't the product of some far-fetched speculativism, though. Conceptual preliminaries already took place in the aftermath of the World War II, when architecture and cybernetics began to cooperate in university environments. For example, during his PhD studies at the Architectural Association in London, Ranulph Glanville designed a shopping system in place of a supermarket. The shopper had a catalogue, phoned up and then dialled in codes for the items he wanted. The items were kept in an automated warehouse. ${ }^{26}$ Absentee Shopping (1970) would work only with a fully-automated warehouse structure, accessed remotely, operated by an array of programmed arms and floating carriers (the designer envisaged a fleet of remotely-operated balloons), very much like the hovering swarm in Autofac (2018). It also uses scenario-like narratives that appeal to readers' own values and expectations, for example by explaining customers' predilection to see perishable foods prepared in front of them, by suggesting a punchcard based retail ordering process and autonomous drone delivery [as it is currently under development by Amazon, 2016 - M. S.] using motorcycle-engine-powered balloons. ${ }^{27}$ 


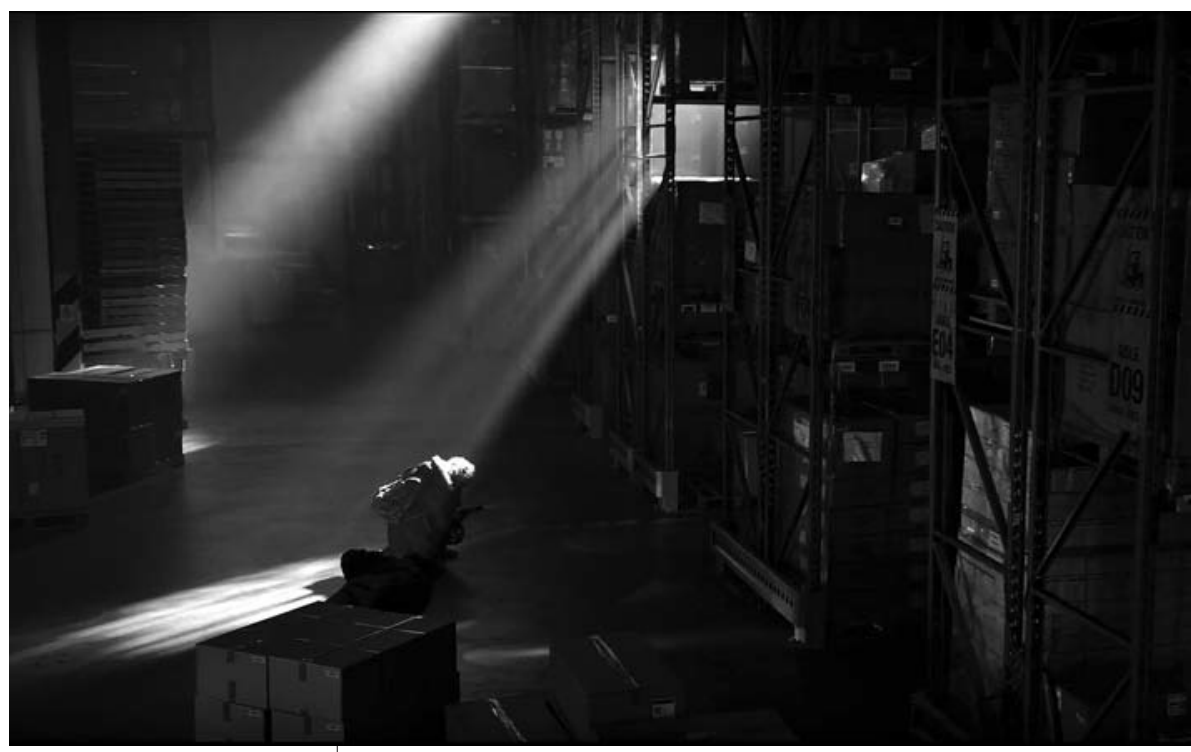

Abandoned warehouse guarded by canine automata from Black Mirror: Metalhead (dir. David Slade, 2017)

Fiction that engages in speculative mode via a pan-automation paradigm rarely focuses on facilitation of services, stressing aspects of it that pose potential threats for the user; threats that reside in algorithms' blind spots. In David Slade's Metalhead (2017) - the Black Mirror episode - a small group of looters breaks into a derelict (Amazon) warehouse, searching for an item whose exact location has been assigned to it by the AS/RS system. Retrieval, however, turns out to be lethal as each member of the party is hunted down by a sentry robot dog guarding the now defunct storage. Frantically typing in codes: 1771, 180061, a man in the car navigates the team that explores the multitier warehouse. Another code - 95-DY42 - designates the item's number and has been written down with a felt-tip pen on a woman's wrist. In Metalhead humans don't just feel like trespassers. The space was designed in a deliberately unintuitive manner. Bar codes, chains of unintelligible signs, QR patterns - all these enable immediate recognition when read by machines. Human-wise, they are abstract maps whose coordinates are unreadable without proper equipment, not to mention such obstacles as complete darkness inside. Visualize dark factories in which complex manufacturing and assembly carries on in cacophonous clamor, but without illumination because robots do not require visible light to sense and move and make. ${ }^{28}$ - writes Benjamin $\mathrm{H}$. Bratton on the prospected architectural settings. Metalhead's warehouse is one of them. Finally, the item is located. A dark polished object rests on the same shelf. Upon removing the box, the glistening object shoots a mist of tracker shrapnels into the air. A previously sleeping guard dog activates itself and goes straight into predatory mode. His vision is a LIDAR scan of the terrain with face recognition algorithm, and it does well without UV light. Intruders will have been eliminated. It's just a matter of time.

A lot has been written on Amazon's order picking process, describing it in self-contradictory terms as 'organized chaos'. We were allowed merely a glimpse 
of it in a sequence from Autofac. It is difficult to find the entrance, and not simply because of the murmuration of drones in this towering monumental structure. In a quick montage cut we see a transition from the airship flying into a cavernous (not only in terms of dimensions, but also its appearance) entrance, to a packing line that disregards speed limits. Inventory fills the entire 'cavern' up to its dimly lit ceiling, therefore the warehouse gives off a monochromatic, steel grey look, and only the drones' red LEDs disrupt this monotony. Such colour choices bring the episode closer to the palette of the Terminator series, but also closer to Metalhead, which was shot entirely in black and white. Machine world is cold, austere, and what unsettles viewers the most - colourless.

\section{c) Data bunker}

Emma Charles conceived her documentary White Mountain (2016) as a journey into the heart (or brain) of a data centre. Undergrowth in a forest full of light, mists floating above the surface of a lake - such dormant natural landscape is bound to subside in a film on technology, shoved aside with a penetrating drone that will lead us underground. Mechanic clangs, air conditioning causing tinnitus, even bleeps seem louder in the subterranean chambers filled with stacks upon stacks of servers. If this is the new silence of robotic whispers, then the end is very likely to slip beneath our radars with a really low frequency whimper. But this vanguard sorrow is nothing like the data centres we came to know through action, crime, and science fiction films.

Whereas excursions into cyberspace were the prime staple of films like Hackers (Iain Softley, 1995) or The Lawnmower Man (Brett Leonard, 1992), visual wizardry had to be pushed back when true coding started to influence not just the spectacle, but the plot. At the same time, hardware architecture expanded as well, and with the $21^{\text {st }}$ century questions concerning material infrastructures of the Internet began to gain merit. Every era has had its own iconic architectural typology. The dream commission was once the church, Modernism had the factory and then the house; in the past decade we celebrated the decadent museum and the gallery. Now we have the data centre. ${ }^{29}$ Even though buildings hosting server clusters/farms might not be perceived as extravagant or appealing, they become less and less evocative of typical boxes. With energy consumption reaching levels of small towns, the containers are designed to resist server sprawl. Density of the stacks, efficiency of cooling systems, and floor plans need to be easily accessible, yet they could just as easily be submersed in total darkness. Alongside technical parameters come characteristics directly connected to the site, namely: proximity to power grids, emergency services, transportation lines, telecommunications infrastructure, and networking services. Another factor deemed as top priority concern is their surplus energy waste. Companies are forced to relocate to colder climates, and thus Iceland, Switzerland, Greenland and subpolar regions are likely candidates for an accelerated meltdown.

Finally, if we consider the data bunker symbolically, it emerges as a place inscribed with temporal recovery plan. Its vital temporality makes the bunker an existential place: a socially and culturally constituted womb from which objects, people, and information are meant to be recovered - and a tomb when recovery becomes impossible. ${ }^{30}$ Such permanence is suggested by their design. Headlines frequently report on projects that come as an alternative to creating new structures in this area. Among 


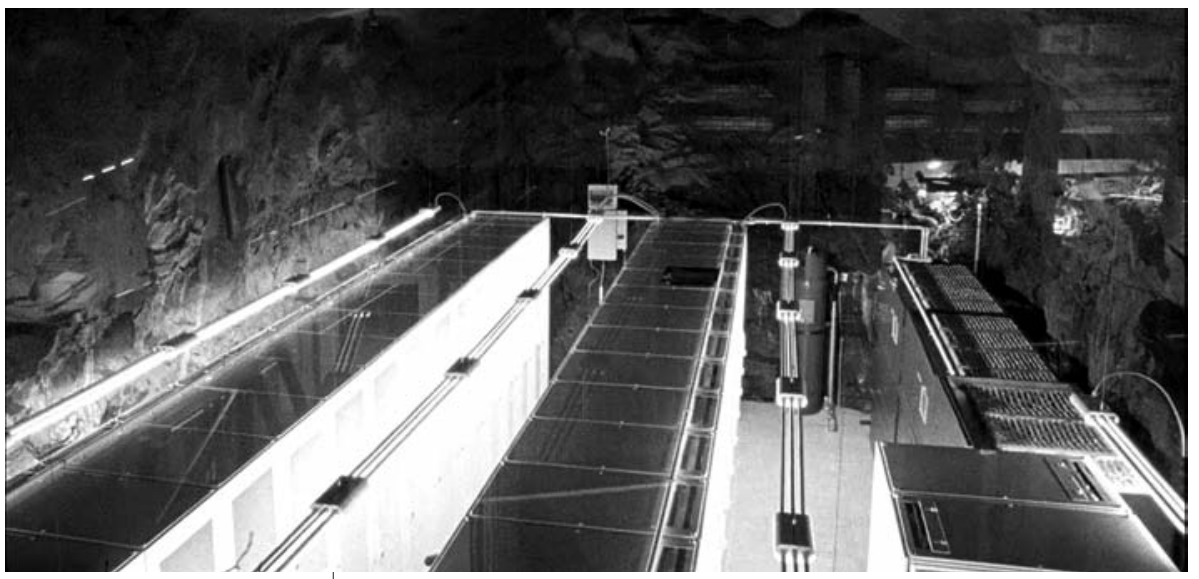

Pionen data centre in Stockholm from White Mountain (dir. Emma Charles, 2016)

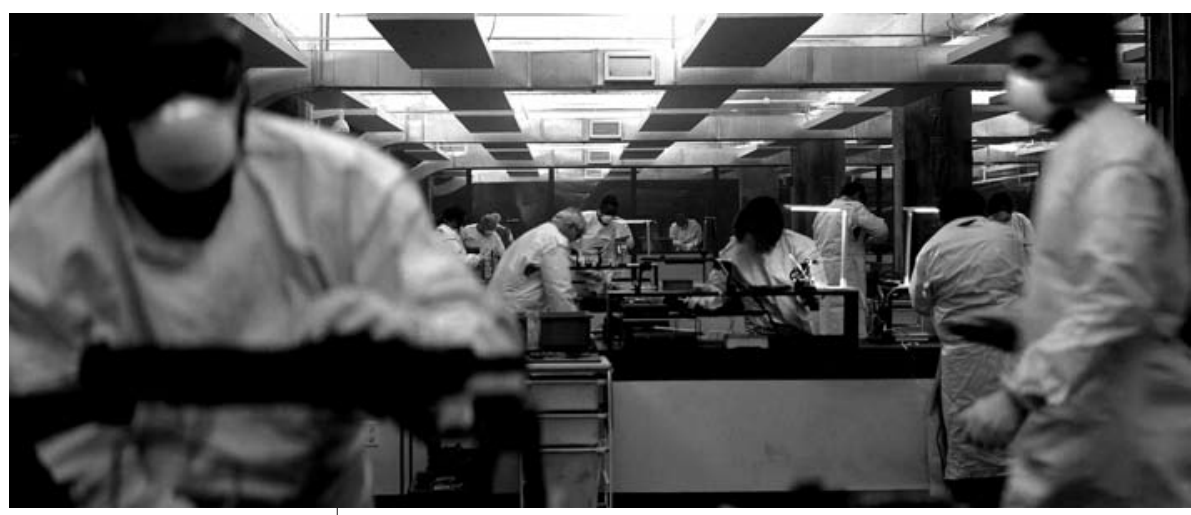

Workers in yellow suits (after Burtynsky) from Captive State (dir. Rupert Wyatt, 2019)

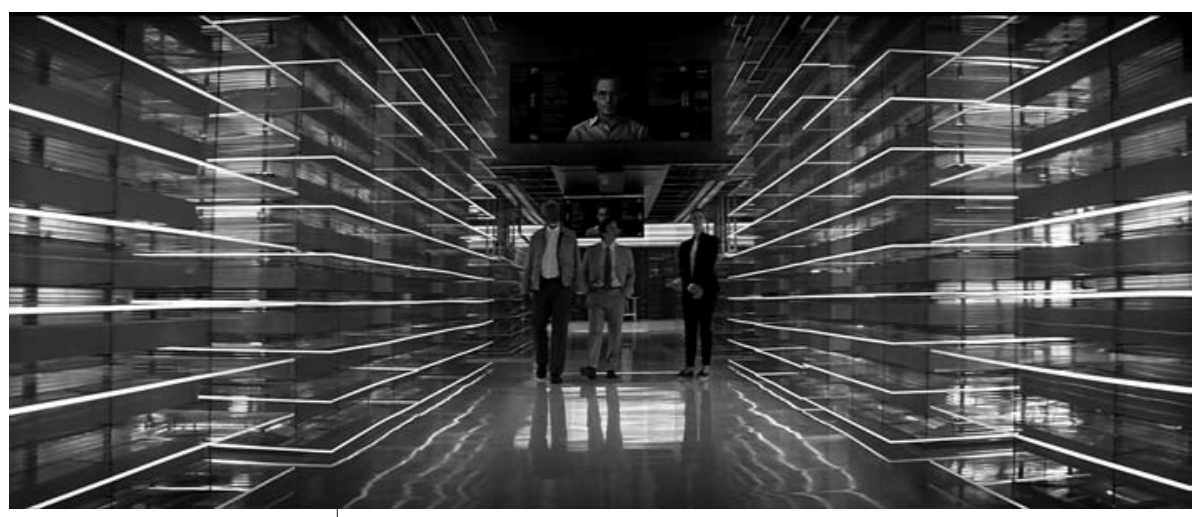

Brazen, translucent data centre, after transmigration from Transcendence (dir. Wally Pfister, 2014) 
types picked for such adaptive reuse, bunkers built during the Cold War attract much interest, as if massive doors and underground tunnels prepared for a Third World War scenario were ideally suited for safe data storage. Maybe they are. Not for armour, though, but for location and temperature - again, rather hostile to the overseers. But the architectural connotation of security is neither strange nor new. Otto Wagner's Austrian Postal Savings Bank (1906), although built in reinforced concrete, had to employ purely ornamental bolts and rivets to connote firmness of steel structures, even though the cladding was marble, and steel constituted its foundations. In general, data centers are designed with security in mind: they lack windows by design and their interiors are often divided into security zones, with the most secure being in the very inner core of the building. On the other, designing a safe space for data and computation security is not the same thing as creating permanence. ${ }^{31}$

The data centres in films are usually hidden inside corporate buildings, preferably in their best-protected parts, and are depicted as fortresses (by both Wagner's and IT standards). They are substantial events in the plot, because protagonists break into them in the course of near-to-impossible missions, hacking these digital vaults in: TRON: Legacy (2010, Joseph Kosinski); Terminator: Dark Fate (2019, Tim Miller); Paranoia (2013, Robert Luketic). No longer transparent or ghostlike, data centres became $21^{\text {st }}$ century's banks. Unsurprisingly, cinema delineates a clear typological evolution of such spaces, from banks to data bunkers, exchanging a monetary reserve for digitized memory. Extinction might be postponed, though not indefinitely. Still, it is the physical database, a digital library, that will allow humankind to be reborn, although in a shape that would be determined by genetic engineering in I Am Mother (2019, Grant Sputore), or - according to Spectral (2016, Nic Mathieu) - necromancy. In the vast majority, scenes written around data centres hardly ever diverge from the scheme that necessitates astounding the viewer with an establishing shot, in which every CPU in the 'cloud' is put on display. It's an IT department's idea of what a money shot should be. Alternately, the shot comes close either to a panorama, or a bird's-eye view, emphasizing a bona fide 'machine landscape' replete with buzzing noise replacing the sound of crickets.

In the same sweeping pan, the camera slides down showing first a large exterior resembling a pile of domino blocks, then a darkened 'library' of processing units, in a day for night continuity shot. Rathium Data Center in Mexico City, as the title of that location in Terminator: Dark Fate indicates, is a short stopover in Rev-9's hunt for Dani, a new threat for the sustainability of future machine endeavours. The Rev-9 terminator hacks into the database to scan for traces fugitives must have left passing by any one of the government-surveilled places - airports, street corners, not to mention border crossings. There are plenty to choose from. The data centre's interior is lit from below with faint, sickly emerald light. Luketic's Paranoia makes some room in the plot for supplementing a generic bank robbery sequence for a data centre 'inside job', whereas the sequel to a cybergeek classic, i.e. TRON: Legacy, begins with a leftist diversion of corporate policy. Targetting his father's firm (ENCOM), Sam Flynn 'breaks into' the company's data centre to leak their latest operating system online, for free. This subversive action earns him applause from the last of the garage programmers still left on the board (of directors). Unlike in Terminator or Paranoia, the ENCOM's mind-hive is designed for user's comfort and visual pleasure - that is, if one is a Kubrick-obsessed masochist. Its 
colour scheme is integrated, low key, and 'painted' monolithic coal black tint. Red and green lights delineate the outlines of units on the ground floor. This army of corporate intelligence prefigures the artificial one, which Flynn will meet in the Grid (minus the turquoise), although in Tron it has been refurbished by $\mathrm{Clu}$ - the film's corrupted software in residence.

However, data centres enter cinema also under more visually specified typologies, combining an espionage caper military complex with a bunker. This can be seen in Spectral and I Am Mother. When fighting supernatural beings, a division of spec-ops comes across a secret research facility located in the lower levels of an enemy plant. There they discover the horrid truth. Scientists working under the former authoritarian state were scanning soldiers and civilians 'on a molecular level', subsequently 3D printing them into spectral assailants. As shocking as the removal of one's brain and nervous system might be, the lab itself provides little comfort with its curiosity cabinet display of removed and preserved body slices. In yet another vault our protagonists find remaining 'souls' plugged into a CPU's brain that steers the apparitions, while keeping them alive. If each cell could be compared to a shop display, then the chamber performs as a stack of biomechanical servers - a data centre whose nexus is us. Although the Australian film I Am Mother takes its audience to an underground data storage that is run by a robot with genuinely maternal feelings, the floor plan of the bunker - delineating coiling corridors, labs and freezers for genetic materials - looks as if it was designed mainly for machine's fulfilment. Contrary to the Terminator franchise, there is no 'superfluous dehumanization' in Sputore's film, maybe because the central aim of this underground complex is to reboot humanity. The eponymous $\mathrm{AI}$ is meant to grow a human child from the embryo, then raise it. It is supposed to teach her 'daughter' ethics and other skills necessary for survival. Just like in Spectral, the archive is prepared for storing condensed human characteristics as data for crunching. It is as much a warehouse as it is a library, therefore it may be treated as a data centre fabricated for maintaining these soft tissue components alive. Eternally plugged, they form a network that spans the entire globe. One could even hear the echo of the vital plea, resounding in the final episode of Devs (2020, Alex Garland): I just need you to help me, to keep it switched on.

Rupert Wyatt's Captive State (2019) (co-written with Erica Beeney) is a dystopian fiction that walks a thin line between a political thriller and a conspiratorial drama. In the aftermath of an invasion, the aliens set up ghettos, restricted districts and an expanded network of surveillance centres. Gabriel works at the recovery section of a Data Reclaim Center - an institution created to get hold of human knowledge ${ }^{32}$. Masked employees in yellow suits are reminiscent of the Asian shoe factory workers in Burtynsky's photographs. Not unlike e-waste processing villagers living in Guiyu, in the Guangdong Province of China, they take cellphones, smartphones and hard discs apart to harvest undeleted files and browser histories, uploading them to an alien mainframe computer, suspended over the city of Chicago. The script written by Erica Beeney and Rupert Wyatt addresses a "drosscape" economy, although relocating it from some far-off periphery to the heart of the city. Just as the developing countries became EU and US 'dumping grounds', so are terrestrial cityscapes treated like a 'third world', abundant in slavish workforce. 


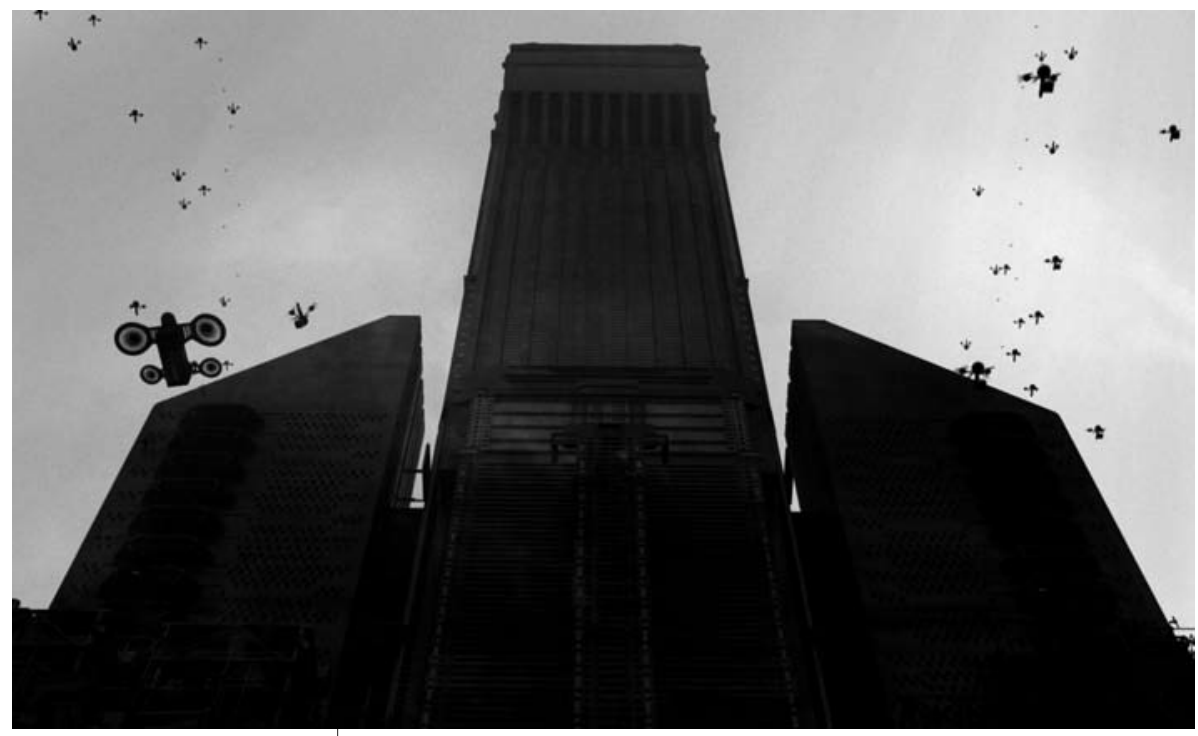

Drones are dispatched from Philip K. Dick's Electric Dreams: Autofac (dir. Peter Horton, 2018)

From an entrepreneurial point of view there is probably no better risk assessment feature film, apparently modelled after a PowerPoint presentation, than Wally Pfister's Transcendence (2014). Transcendence forces upon its viewer a vision of a post-human evolution, according to which man merges with the machine. Will Caster - a scientist whose research on artificial intelligence brought him international recognition and infamy among Luddites - becomes lethally wounded by a member of an extremist group called RIFT. Facing inevitable death, his wife, Evelyn, uploads his mind into a quantum computer, and subsequently to the World Wide Web. Although harshly criticized, the film is actually moderately intelligent in conveying a post-humanist perspective put forward by N. Katherine Hayles and Robert Pepperell, who argue that a hypothetical transfer of one's consciousness into machine environment would not leave the mind unaltered by the change of medium as radical as this. The mind and the body act together to produce consciousness. If one is absent consciousness ceases. ... Consciousness is an effect that arises through the co-operation of a brain and body; we think with our whole body. ${ }^{33}$ In the case of Transcendence Caster's new body it is the data centre built in a small town of Brightwood ${ }^{34}$, and subsequently the expanded infrastructure of the global network. Even though a battery of solar panels wouldn't probably be enough in real life (a degree of utopian wishful thinking should not feel out of place in speculative fiction), the infinite and sterile white corridors, glass walls giving an illusion of transparency, and angular geometries of the subterranean complex look convincingly banal. Model boxes placed in modest settings. Housed within a cluster of blank warehouses are the endless rows of server stacks and processors that now contain everything about who we are. All of our images, books, music, inane chatter, ... drowning in the constant whir of cooling fans. Terms like 'cloud', 'wifi' and 'web' are suggestive of something omnipresent, ephemeral, everywhere and nowhere, yet this network is organised around an extraordinary planetary-scaled physical infrastructure. ... The Google Farm is not a great library or 
a grand cathedral, but when our collective history is digital, this is our generation's cultural legacy. ${ }^{35}$ Neglecting technological fantasies on nanotechnology in Transcendence, or the soul engineering in Spectral, we're still only a step away from finding ourselves contained within an intelligent cloud. Eventually, it might turn out to be too material for our inchoate daydreaming.

\section{Conclusion: tales from a sustainable loop}

In each of these typologies, according to Hollywood's forecasts, there hatches an embedded "human exclusion zone" - an area that is scheduled for a progressive automation in the near future, thus heralding human redundancy lurking on the horizon. Films like I Am Mother, Blade Runner 2049 or Transcendence explicitly show how such architectural setting could easily be run by artificial intelligence, even in instances of retaining human scale as measure. Alas, most interiors are vast, seemingly impossible to traverse, and if operational, then definitely not by an un-engineered stride. Just like the post-Amazonian warehouse of the autofac in the adaptation of Dick's short story, a swarm of drones buzzing is what breaks the silence - neither the footsteps nor the workers' chatter.

Focusing too much on infrastructures, "stim" and "dross" that would terraform the landscape after the dusk of human age, we might miss out on ecologically-oriented, sustainable projects with which the Anthropocene is increasingly entering the architect's lexicon. ${ }^{36}$ Buildings that minimize their footprint and their contribution to global warming, yet whose scale begins to encompass cities, being close to geological in terms their impact. Burtynsky's photo shoots are again a telling counterpart to this dynamics, showing, for example, the Three Gorges Dam project in China as an undertaking in engineering the natural habitat at an unprecedented scale. A call to arms for productive engagement with the machine world would only be possible through new architecture centred both on the human and the habitat; one that is not an intrusion, but a site-specific remodelling of a landscape. Sceneries relegated to the rims of our progressively smarter cities, discussed here on the basis of their film doppelgängers, reveal a dehumanized future we fear. In this they are caricatures, emphasizing features and aspects of design that could turn them into human-proof autofacs, unless... Falling into the Post-Anthropocene does not mean the abandoning of all that came before it. ... These sites are not warning signs, they are not cautionary tales of what could happen. ... They are just setdressing the waiting rooms, distracting us with expressive displays while the machines program our planet, hidden behind windowless walls and anonymous forms. ${ }^{37}$

Until then, data centres and automated warehouses will become cooler, denser, and more energetically hungry. They will operate with a very limited staff, which is likely to diminish even more in the foreseeable future. Long sequences from White Mountain present - for our inspection - dimly lit corridors, and rooms immersed in (nearly) complete darkness. As the machine vision turns sharper, occasional supervisors monitoring the equipment could even come blind as moles, given the fact that their presence on the ground floor ceases to be necessary. And the lack of lights is frugal - no excess heat, no energy wasted. The future is coming. Lights out! 
${ }^{1}$ L. Young, "Not For Us: Squatting the Ruins of Our Robot Utopia. An Interview with Paul Inglis, Supervising Art Director of Blade Runner 2049", Architectural Design 2019, vol. 89 , no. 1 , p. 128 .

${ }^{2}$ The title is an acronym combining the words "automatic" and "factory".

${ }^{3}$ J. Odell, Satellite Landscapes (Transportation Landscape, Waste Landscape, Manufacturing Landscape, and Power Landscape) 2013-2014, http://www.jennyodell.com/satellite-landscapes.html (accessed: 12.04.2020).

${ }^{4}$ A concept made popular by Alan Berger, although originating from Lars Lerup's essay where dross is characterized as ...the ignored, undervalued, unfortunate economic residues of the metropolitan machine. (L. Lerup, "Stim \& Dross: Rethinking the Metropolis", Assemblage December 1994, vol. 25, p. 93).

${ }^{5}$ R. Koolhaas, B. Mau, S, M, L, XL, Monacelli Press, New York 1995, pp. 495-516.

${ }^{6}$ A reference to architectural design parameters.

${ }^{7}$ D. Koch, "Changing Building Typologies: The Typological Question and the Formal Basis of Architecture", Journal of Space Syntax 2014, vol. 5, no. 2, p. 169.

8 A. Rossi, The Architecture of the City, MIT Press, Cambridge and London 1984, p. 40.

${ }^{9}$ W. Braham, "After Typology: The Suffering of Diagrams", Architectural Design 2000, vol. 70 , no. 3, p. 9.

10 R. Moneo, "On Typology", Oppositions: A Journal for Ideas and Criticism in Architecture 1978, vol. 13, p. 27.

${ }^{11}$ Idem, p. 32.

${ }^{12}$ K. Schwab, "The Fourth Industrial Revolution", World Economic Forum, Cologne and Geneva 2016, p. 79.

${ }^{13}$ Although it has to meet a set of expectations for such structures, required for an efficiently running network.

14 Z. Saunders, "Interview with Liam Young", ARCH20, https://www.arch2o.com/interview-liam-young-arch2o/ (accessed: 12.04.2020).

${ }^{15}$ L. Young, “Territorial Robots. Jenny Odell: Satellite Landscapes", Architectural Design 2019, vol. 89, no. 1, p. 35

${ }^{16}$ L. Young, "Introduction. Neo-Machine: Architecture Without People", Architectural Design 2019, vol. 89 , no. 1, p. 11.

${ }^{17}$ A. Berger, Drosscape: Wasting Land in Urban America, Princeton Architectural Press, New York 2006, p. 1.

${ }^{18}$ Idem, p. 34.

${ }^{19}$ L. Lerup, op.cit., p. 99.
${ }^{20}$ L. Young, "Not For Us", op. cit., p. 128.

21 film dialogue from Blade Runner Black Out 2022 (Shinichiro Watanabe, 2017)

${ }^{22}$ film dialogue from Blade Runner 2049 (Denis Villeneuve, 2017)

${ }^{23}$ R. Hart, The Warehouse: A Novel, Crown, New York 2019, p. 313.

${ }^{24}$ L. Young, "A Place for Everything. Ben Roberts: Amazon Unpacked", Architectural Design 2019, vol. 89, no. 1, p. 47.

25 S. Taylor, M. Cooper, and P. S. Barnwell, Manchester: The Warehouse Legacy. An Introduction and Guide, English Heritage, London 2002, p. 6.

${ }^{26}$ N. Spiller, Visionary Architecture: Blueprints of the Modern Imagination, Thames and Hudson, London 2007, p. 206.

27 T. Fischer, "Defaceable System MK 4 and Brent Shopping Yr 3", in: Ranulph Glanville: Architecture, Art, Cybernetics, Design - London and the 1960s, eds. M. Ertl, W. Korn, A. Müller, Edition Echoraum, Vienna 2016, p. 66.

${ }^{28}$ B. H. Bratton, The Terraforming, Strelka Press, Moscow 2019, p. 33.

${ }^{29}$ L. Young, "Introduction”, op. cit., p. 9.

${ }^{30}$ A. Fish, and B. L. Garrett, "Resurrection from Bunkers and Data Centers", Culture Machine: Generating Research in Culture and Theory 2019, vol. 18, p. 1 (no pagination).

31 J. Velkova, "Data Centers as Impermanent Infrastructures", Culture Machine: Generating Research in Culture and Theory 2019, vol. 18, p. 4.

32 Apparently, alien invaders are more inclusive than Wikipedia. They recognize that the big data paradigm is only useful when it encompasses all the data ever produced.

${ }^{33}$ R. Pepperell, "The Posthuman Manifesto", Kritikos: an international and interdisciplinary journal of postmodern cultural sound, text and image 2005, vol. 2, https://www.inter_theory.org/pepperell.htm (accessed: 12.04.2020).

${ }^{34}$ Here Transcendence also proves reasonably appealing due to its structure, resembling an essay on the impact of a generic data centre on a small community living in a Rust Belt town.

${ }^{35}$ L. Young, "Where the Internet Lives. John Gerrard: Farm", Architectural Design 2019, vol. 89, no. 1, p. 59.

${ }^{36}$ N. Korody, "Architecture of the Anthropocene, Part 1", Archinect, https://archinect.com/features/article/109656462/architecture-of-the-anthropocene-part-1 (accessed: 13.04.2020).

${ }^{37}$ L. Young, “Introduction”, op. cit., p. 13. 
Maciej Stasiowski

$\mathrm{PhD}$ in arts and humanities; graduate of the Institute of $\mathrm{Au}-$ diovisual Arts at the Faculty of Management and Social Communication, Jagiellonian University in Krakow. His academic interests include time-based techniques of audiovisual representation (live action and animated film, installation art, new media), and their role in experimental architectural projects. He published articles in ARCH, Ekrany, TransMissions and Kultura i Historia; the author of a book on Peter Greenaway's literary influences entitled Atlas rzeczy niestatych [The Atlas of All Things Inconstant] (2014).

\section{Bibliography}

Bedir, M., Hilgefort, J. (2019). Fringes of Technology and Spaces of Entanglement in the Pearl River Delta. Architectural Design, 89 (1), pp. 78-83.

Berger, A. (2006). Drosscape: Wasting Land in Urban America. New York: Princeton Architectural Press.

Braham, W. (2000). After Typology: The Suffering of Diagrams. Architectural Design, $70(3)$, pp. 9-11.

Bratton, B. H. (2013). Some Trace Effects of the Post-Anthropocene: On Accelerationist Geopolitical Aesthetics. $e$-flux, 46, https:/www.e-flux.com/journal/46/60076/sometrace-effects-of-the-post-anthropocene-on-accelerationist-geopoliticalaesthetics/

Bratton, B. H. (2019). Further Trace: Effects of the Post-Anthropocene. Architectural Design, 89 (1), pp. 14-21.

Bratton, B. H. (2019). The Terraforming. Moscow: Strelka Press.

Fischer, T. (2016). Defaceable System MK 4 and Brent Shopping Yr 3. In: M. Ertl, W. Korn, A. Müller (eds.), Ranulph Glanville: Architecture, Art, Cybernetics, Design London and the 196os (pp. 63-70). Vienna: Edition Echoraum.

Fish, A., Garrett, B. L. (2019). Resurrection from Bunkers and Data Centers. Culture Machine: Generating Research in Culture and Theory, 18 (1), pp. 1-14.

Hart, R. (2019). The Warehouse: A Novel. New York: Crown.

Koch, D. (2014). Changing Building Typologies: The Typological Question and the Formal Basis of Architecture. Fournal of Space Syntax, 5 (2), pp. 168-189.

Koolhaas, R., Mau, B. (1995). $S, M, L, X_{L}$. New York: Monacelli Press.

Korody, N. (2014, September 29). Architecture of the Anthropocene: Part 1. Archinect.com. https://archinect.com/features/article/109656462/architecture-ofthe-anthropocene-part-1

Lerup, L. (1994). Stim \& Dross: Rethinking the Metropolis. Assemblage, 25, pp. 82-101.

Moneo, R. (1978). On Typology. Oppositions: A fournal for Ideas and Criticism in Architecture, 13 , pp. 22-45.

Odell, J. (2014). Satellite Landscapes (Transportation Landscape, Waste Landscape, Manufacturing Landscape, and Power Landscape) 2013-2014. Jennyodell.com. http://www.jennyodell.com/satellite-landscapes.html 
Pepperell, R. (2005). The Posthuman Manifesto. Kritikos: An International and Interdisciplinary fournal of Postmodern Cultural Sound, Text and Image, 2. https://www.intertheory.org/pepperell.htm

Rossi, A. (1984). The Architecture of the City. Cambridge - London: MIT Press.

Schwab, K. (2016). The Fourth Industrial Revolution. Cologne - Geneva: World Economic Forum.

Spiller, N. (2007). Visionary Architecture: Blueprints of the Modern Imagination. London: Thames and Hudson.

Taylor, S., Cooper, M., Barnwell, P. S. (2002). Manchester: The Warehouse Legacy. An Introduction and Guide. London: English Heritage.

Velkova, J. (2019). Data Centers as Impermanent Infrastructures. Culture Machine: Generating Research in Culture and Theory, 18 (4), pp. 1-11 (no pagination).

Vonderau, A. (2019). Storing Data, Infrastructuring the Air: Thermocultures of the Cloud. Culture Machine: Generating Research in Culture and Theory, 18 (5), pp. 1-12 .

Young, L. (2019). A Place for Everything. Ben Roberts: Amazon Unpacked. Architectural Design, 89 (1), pp. 45-47.

Young, L. (2019). Introduction. Neo-Machine: Architecture Without People. Architectural Design, 89 (1), pp. 6-13.

Young, L. (2019). Not For Us: Squatting the Ruins of Our Robot Utopia. An Interview with Paul Inglis, Supervising Art Director of "Blade Runner 2049”. Architectural Design, 89 (1), pp. 126-135.

Young, L. (2019). Territorial Robots. Jenny Odell: Satellite Landscapes. Architectural Design, 89 (1), pp. 32-35.

Young, L. (2019). Where the Internet Lives. John Gerrard: Farm. Architectural Design, 89 (1), pp. 56-59.

\author{
Slowa kluczowe: \\ architektura; \\ typologia; \\ film; \\ science fiction; \\ postantropocen
}

\begin{abstract}
Abstrakt
Maciej Stasiowski

Krajobraz bez postaci. Postantropocentryczne typologie architektoniczne w kinie fantastyczno-naukowym

Fabryki, zautomatyzowane magazyny, elektrownie oraz centra danych już dziś funkcjonują najlepiej przy minimalnej ingerencji. Co istotniejsze, przestrzenie tego typu wymykają się tradycyjnym typologiom, także dlatego, że swoją skalą i przeznaczeniem zrywają z antropocentrycznym charakterem architektury. Od człowieka witruwiańskiego po modulor Le Corbusiera ciało ludzkie stanowiło miarę budowli. Co jednak w przypadku konstrukcji przeznaczonych na magazyny, centra logistyczne, farmy serwerów obsługiwanych przez maszyny bądź których automatyzacja gwałtownie postępuje? Na to pytanie ma odpowiedzieć niniejszy artykuł. Autor analizuje w nim ikonografię przestrzeni pro-
\end{abstract}


jektowanych niejako na erę mającą nadejść „po człowieku” przez pryzmat fantastyki naukowej, a więc filmów, w których sztuczna inteligencja jest integralnym komponentem środowiska, takich jak: Blade Runner 2049 (reż. Denis Villeneuve, 2017), Rebelia (reż. Rupert Wyatt, 2019), Jestem matka (reż. Grant Sputore, 2019) czy Transcendencja (reż. Wally Pfister, 2014).

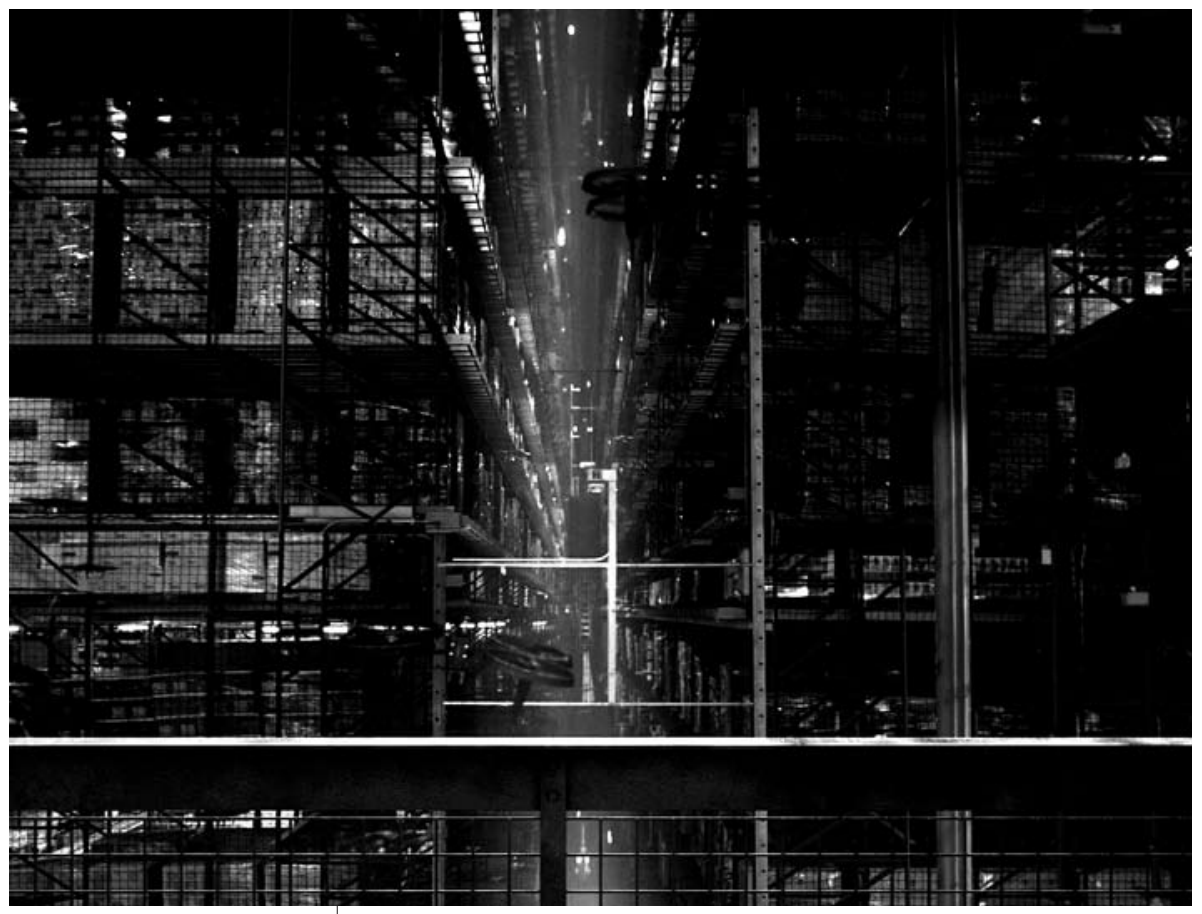

The warehouse in all its immensity from Philip K. Dick's Electric Dreams: Autofac (dir. Peter Horton, 2018) 